\title{
Iringan Karawitan Pergelaran Wayang Golek Menak Yogyakarta Versi Ki Sukarno
}

Aji Santoso Nugroho

Jurusan Musik Nusantara, Program Pascasarjana, Institut Seni Indonesia Yogyakarta

Email: ajisantosonugroho@yahoo.co.id

\begin{abstract}
This article aims to describe the musical accompaniment in the Menak Sukarno Golek Golek performance by Ki Sukarno. Musicology analysis is done using karawitan to reveal the structure, shape, workmanship, and function of karawitan in Ki Sukarno's Menak Yogyakarta Golek Puppet show. From the observations of Ki Sukarno's performance, it was concluded that the accompaniment of Menak Puppet Golek music used in the performance was basically not much different from the wayang kulit of Yogyakarta puppet. The difference between the two lies in the laya or rhythmic dish and the obstacle pattern, namely the wayang motion, the ater open the playon and the playon level. Laya or rhythm used refers to dance music and the pattern of resistance. This is because in the Menak Puppet Puppet contains elements of dance movement vocabulary. The performances of Menak Golek Puppet have a standard composition as accompaniment, namely the Gending Goal of Kabor Topèng, Orange Flower Sifter, Playon Kembang Jeruk, Playon Gégot, and Playon Gambuh. Karawitan in the performance of Menak Golek Puppet serves as a confirmation of scene changes, emphasizes the atmosphere of the scene, reinforces dramatic elements, emphasizes the character, and reinforces the character of puppet movements. The presentation structure of Menak Yogyakarta Golek Puppet refers to the structure of Purwa Yogyakarta Puppet Leather, both from the structure of the division of the scene, to the use of gamelan which only uses sléndro tunings. The element that distinguishes it is only found in the scene ajon-ajon or majeng beksa, namely the motion of dance before committing a war and a fierce war scene.
\end{abstract}

Keywords: musical accompaniment; wayang golek menak; Ki Sukarno

\begin{abstract}
Abstrak
Artikel ini bertujuan mendeskripsikan iringan karawitan dalam pergelaran Wayang Golek Menak Yogyakarta versi Ki Sukarno. Analisis musikologi garap karawitan digunakan untuk mengungkap struktur, bentuk, garap, dan fungsi karawitan dalam pertunjukan Wayang Golek Menak Yogyakarta versi Ki Sukarno. Dari pengamatan terhadap pergelaran Ki Sukarno didapatkan kesimpulan bahwa iringan karawitan Wayang Golek Menak yang digunakan dalam pergelarannya pada dasarnya tidak berbeda jauh dari karawitan Wayang Kulit Yogyakarta. Perbedaan dari keduanya terletak pada sajian laya atau irama dan pola kendhangan yaitu ater-ater gerak wayang, ater-ater buka playon dan suwuk playon. Laya atau irama yang digunakan mengacu pada karawitan tari dan pola kendhangan. Hal ini dikarenakan dalam Wayang Golek Menak terkandung unsur vokabuler gerak tari. Pergelaran Wayang Golek Menak mempunyai gending baku sebagai iringan yaitu Ketawang Gending Kabor Topèng,
\end{abstract}




\begin{abstract}
Ayak-ayak Kembang Jeruk, Playon Kembang Jeruk, Playon Gégot, dan Playon Gambuh. Karawitan dalam pergelaran Wayang Golek Menak berfungsi sebagai penegas pergantian adegan, penegas suasana adegan, penegas unsur dramatik, penegas karakter tokoh, dan penegas karakter gerak wayang. Struktur penyajian Wayang Golek Menak Yogyakarta mengacu pada struktur Wayang Kulit Purwa Yogyakarta, baik itu dari struktur pembagian adegan, sampai penggunaan gamelan yang hanya menggunakan laras sléndro. Unsur yang membedakannya hanya terdapat pada adegan ajon-ajon atau majeng beksa, yaitu gerak tarian sebelum melakukan perang dan adegan perang gecul.
\end{abstract}

Kata kunci: iringan karawitan; wayang golek menak; Ki Sukarno

\section{Pendahuluan}

Pada dasarnya gamelan atau karawitan tradisional di lingkungan masyarakat (Jawa) disajikan tidak terlepas dari fungsi dan kegunaannya untuk berbagai keperluan atau peristiwa. Dalam penyajian pertunjukan wayang, kedudukan karawitan berkaitan dengan pembabakan maupun pengadegan, dan berperan penting dalam memperkuat atau mempertegas unsur dramatik. Rahayu Supanggah (2009: 310) menyebutnya dengan istilah karawitan pakeliran. Sementara itu untuk menyebutkan komposisi musikal, para pengrawit menyebut karawitan tersebut sebagai gending wayangan, yaitu gending-gending yang biasa digunakan untuk mendukung pertunjukan Wayang Kulit Purwa, kemudian juga untuk Wayang Golek, Wayang Madya, dan Wayang Gedhog.

Penggunaan gending wayangan telah dibakukan dalam penyajiaannya, dan disesuaikan dengan pertunjukan wayang yang disajikan. Bambang Murtiyoso (2004: 114) menyebut gendinggending tersebut sebagai gending pokok (baku), yaitu gending yang digunakan untuk keperluan mendukung suasana bangunan lakon yang dikelirkan, sejak dari jejer sampai tanceb kayon (kecuali bagian limbukan dan gara-gara). Penyajian atau pembabakan tradisi Wayang Kulit Purwa Gaya Yogyakarta terbagi dalam tiga bagian yang terbingkai dalam pathet, yaitu pathet nem, pathet sanga, dan pathet manyura. Masing-masing pathet terbagi sesuai dengan pengadegan dalam masingmasing babak. Karawitan pakeliran dalam berbagai jenis pertunjukan wayang tentu masing-masing juga memiliki perbedaan dalam perspektif bentuk dan fungsi. Salah satu bentuk karawitan pakeliran tersebut ialah karawitan pakeliran Wayang Golek Menak di wilayah Daerah Istimewa Yogyakarta.

Wayang Golek Menak adalah pertunjukan boneka wayang yang berbentuk tiga dimensi, terbuat dari kayu sebagai bahan bakunya. Kuswaji (1957: 10) menjelaskan wayang golek dibentuk seperti manusia, dibuat dari kayu jaranan, kayu kemiri, dan kayu mentaos (lihat Istanti, 2013). Secara umum, bentuk wayang golek dibagi menjadi tiga bagian yaitu bagian kepala, badan, dan busana. Bagian kepala terdiri dari muka, irah-irahan, serta leher. Bagian badan terdiri dari bahu, torso, lengan serta bokongan, sedangkan bagian busana terdiri dari pakaian dan perabot (Sukistono, 2009). Penyebutan Wayang Golek Menak karena sumber cerita atau lakon yang digunakan adalah Serat Menak. Ditegaskan kembali dalam pernyataan Soetarno yang dikutip oleh Suparto (1999: 22), bahwa sumber cerita atau lakon Wayang Golek Menak menggunakan Serat Menak. Dalam pertunjukan Wayang Golek Menak, karawitan juga berkaitan dengan pembabakan dan pengadegan, mengacu pada penyajian Wayang Kulit Purwa.

Penyajian Wayang Golek Menak banyak menggunakan unsur seni tari. Salah satu unsur tari yang menonjol dalam Wayang Golek Menak terdapat dalam adegan ajon-ajon atau majeng beksa, yaitu gerak tari yang dilakukan oleh dua tokoh wayang sebelum melakukan peperangan. Adegan tersebut tidak terdapat dalam Wayang Kulit Purwa. Adegan-adegan tersebut dalam penyajiannya juga memerlukan garap karawitan secara khusus. Selain gending-gending baku, dalam penyajian Wayang Golek Menak juga menggunakan alternatif atau pilihan gending (diluar gending baku) yang sering digunakan dalam penyajian Wayang Kulit Purwa. 
Pemilihan gending tidak terlepas dari fungsi karawitan terhadap pembabakan maupun pengadegan. Gending yang digunakan biasanya disesuaikan dengan suasana adegan, karakter gending dengan karakter tokoh, dan nama gending dengan adegan atau nama tokoh. Dalang menunjuk (meminta) gending yang akan digunakan untuk adegan tertentu kepada pengrawit dengan menggunakan sasmita, isyarat atau kode, berupa wangsalan yang kemudian diikuti tanda dhodhogan (pukulan cempala pada kotak wayang) atau keprakan (bunyi kecrek yang dihasilkan oleh jejakan kaki kanan dalang atau dapat juga dengan cempala) pada keprak, tiga atau empat lempengan logam (dari besi, kuningan atau perunggu) yang digantungkan menempel pada kotak wayang sebagai tanda memulai buka gending (Supanggah, 1999: 139).

Dalang merupakan subjek utama dalam pertunjukan Wayang Golek Menak. Berdasarkan penelusuran dan penelitian yang dilakukan penulis, beberapa dalang Wayang Golek Menak yang terdapat di wilayah Daerah Istimewa Yogyakarta antara lain Ki Widiprayitna (alm.) dari Kulon Progo, Ki Sukarno (putra Ki Widiprayitna) dari Kulon Progo, Ki Suparman dari Kulon Progo, dan Ki Sudarminta dari Sleman. Dari sekian dalang Wayang Golek Menak tersebut, yang masih eksis, sekaligus mempopulerkan kesenian tersebut kepada masyarakat Yogyakarta adalah Ki Sukarno.

Ki Sukarno adalah dalang sepuh yang memiliki pengalaman tentang Wayang Golek Menak cukup luas. Saat ini Ki Sukarno merupakan dalang paling tua di antara dalang-dalang Wayang Golek Menak di Daerah Istimewa Yogyakarta, yaitu 72 tahun. Aspek lain yang menjadi pertimbangan adalah Ki Sukarno merupakan satu-satunya dalang Wayang Golek Menak yang masih konsisten dalam format pertunjukan tradisi termasuk unsur-unsur karawitan yang digunakan.

\section{Pertunjukan Wayang Golek Menak}

Wayang Golek Menak merupakan salah satu jenis wayang yang menggunakan Serat 'buku' sebagai sumber lakon yaitu Serat Menak. Cerita dalam Serat Menak tersebut bernafaskan Islam, berisi kisah Amir Ambyah (paman Nabi Muhamad SAW). Serat Menak merupakan saduran
Kitab Qisai Emir Hamza yang berasal dari Negara Persia oleh R. Ng. Yasadipura I pada masa Sunan Paku Buwana II (Harpawati, 2009). Melalui hasil saduran kitab tersebut diperoleh beberapa cerita lakon di antaranya adalah Menak Sarehas, Menak Lare, Menak Sarandil, Menak Sorangan, Menak Jamintoran, Menak Jaminambar, Menak Talsamat, Menak Lakat, Menak Kustub dan masih banyak cerita lakon Menak yang lain. Sebagai gambaran, di bawah ini adalah contoh tentang balungan lakon Wayang Golek Menak semalam suntuk versi Ki Sukarno Widiatmaja yang mengambil lakon "Bedah Yahman" (Sukistiono, 1996: 60). Lakon Bedah Yahman terbagi atas 7 jejer dan 7 perang, yaitu:

\section{Patet Nem}

a. Jejer I : Negara Mekah

Tokoh : Adipati Abdulmuntalib, Patih Tambi Jumiril, Raden Abdulah, Raden Abuntalib, dan Raden Abas.

Pada pertemuan tersebut dibicarakan tentang kekhawatiran Adipati Abdulmuntalib karena sudah beberapa kali tidak menyerahkan upeti ke negara Yahman. Pada waktu itu Mekah adalah negara telukan atau di bawah kekuasaan Negara Yahman. Adipati Abdulmuntalib segera mengirim upeti tersebut. Diceritakan pula bahwa pada saat itu Amir Ambyah dan Umar Maya sedang berguru, memperdalam agama Islam kepada Kyai Abdul Syukur Asmaragama di Pondok Bleki. Hal ini merupakan suatu kebetulan sebab apabila mereka berdua mengetahui bahwa Mekah akan mengirim upeti ke Yahman, tentu Amir dan Umar tidak akan menyetujuinya, mengingat watak mereka yang pemberani. Untuk itu diutuslah Raden Abdulah, Raden Muntalib, serta Raden Abbas agar menyerahkan upeti ke Yahman. Mereka bertiga segera memohon diri, mempersiapkan keberangkatannya ke negara Yahman.

b. Adegan : Paseban Jawi

Tokoh : Patih Tambi Jumiril, Raden Abdullah, Raden Abuntalib, Raden Abbas, Tumenggung Abdulpangi dan beberapa orang prajurit.

Diceritakan dalam adegan paseban jawi, Patih Tambi Jumiril mengumpulkan prajurit Mekah. Dalam pertemuan tersebut Patih Tambi Jumiril menjelaskan tentang perintah Adipati Abdulmuntalib agar menyerahkan upeti ke 
Negara Yahman. Para prajurit ditugaskan mengawal perjalanan Patih Tambi Jumiril, Raden Abdullah, Abuntalib, Raden Abbas, dan Tumenggung Abdulpangi menuju Yahman.

Di tengah perjalanan, mereka dihadang oleh gerombolan perampok di bawah pimpinan Singo Barong. Terjadilah pertempuran, rombongan Mekah dapat dikalahkan dan upeti yang semula akan dikirim ke Yahman berhasil direbut. Prajurit Mekah cerai berai dan mundur, Raden Abdullah ditawan dan dipaksa menjadi anggota perampok, prajurit yang berhasil melarikan diri kembali ke Mekah.

c. Jejer II : Jejer Negara Kalabani

Tokoh : Prabu Masban, Raden Karuna, Raden Karuni, dan Raden Maktal.

Diceritakan bahwa pada pertemuan tersebut Raden Maktal mohon pamit dan minta doa restu kepada ayahnya untuk mengembara, mencari pengalaman serta mencoba mengukur sampai seberapa kesaktiannya dengan cara mencari lawan yang dianggap mempunyai kesaktian. Berangkatlah Raden Maktal diiringi Darwis, abdinya. Di tengah perjalanan, dihadang oleh perampok pimpinan Singo Barong yang semula berhasil merampas harta rombongan utusan Mekah. Terjadilah perkelahian di antara mereka. Walaupun Raden Maktal dikeroyok oleh gerombolan tersebut, namun ia berhasil mengalahkan para perampok. Selanjutnya Maktal diangkat menjadi ketua gerombolan perampok dan sementara tinggal di hutan bersama mereka.

d. Jejer III : Jejer Negara Kebar

Tokoh : Prabu Halkamah, Patih Kebarsah, Raden Hoksam, Raden Yusupadi, dan Tumenggung Sastrajaya.

Pada pertemuan tersebut, putra Raja Halkamah yaitu Raden Hoksam mohon diri serta minta doa restu kepada ayahnya. Ia berniat mencari putera Mekah yang bernama Amir dan ingin mengadu kesaktian dengannya. Begitu besar niatnya hingga ia berjanji tidak akan pulang sebelum mampu mengalahkan Amir Ambyah. Alasan Raden Hoksam mengambil sikap ini karena mendengar kabar tentang kesaktian Amir Ambyah. Berangkatlah Raden Hoksam diiringi Tumenggung Sastrajaya beserta beberapa orang prajurit.

\section{Patet Sanga}

a. Adegan: Gara-gara

Tokoh : Jiweng, Toples, dan Bladu.

Ketiga tokoh sebagai abdi tersebut sedang bersenda gurau dalam tugasnya menghantarkan Amir Ambyah dan Umar Maya berguru di Pondok Bleki.

b. Jejer IV : Pondok Bleki

Tokoh : Kyai Abdul Syukur Asmaragama, Amir Ambyah, dan Umar Maya.

Raden Amir Ambyah dan Umar Maya menghadap guru mereka, yaitu Kyai Abdul Syukur Asmaragama. Pertemuan tersebut merupakan pertemuan terakhir mereka dalam berguru. Setelah menerima beberapa ajaran serta nasehat terakhir sebagai pegangan hidup, Raden Amir Ambyah, Umar Maya dan ketiga abdinya mohon pamit pulang ke Mekah.

c. Jejer V : Ngara-ara Kep

Tokoh : Raden Maktal, Singo Barong, Jayabegal, Pelangbego, dan Darwis.

Mereka sedang pesta setelah berhasil merampok harta Mekah. Setelah puas mengadakan pesta, Raden Maktal segera memerintahkan mencari orang yang dianggap sakti untuk ditantang berkelahi dengannya. Mereka berpencar dan berjaga-jaga seperti biasa, menanti dan mencari orang yang dianggap sakti. Perjalanan Raden Amir Ambyah beserta kawankawannya akhirnya sampai di hutan Kep. Raden Amir bertemu dan ditantang berkelahi melawan Raden Maktal. Perkelahian tersebut dimenangkan oleh Amir Ambyah, Maktal takluk dan bersedia masuk Islam serta meninggalkan pekerjaan mereka sebagai perampok. Upeti Mekah akhirnya dikirim kembali oleh Raden Abdullah. Mereka berangkat ke Yahman, berniat menghentikan tindakan sewenang-wenang raja Yahman terhadap Mekah.

\section{Patet Manyura}

a. Jejer VI : Negara Yahman

Tokoh : Prabu Binti Bahram, Patih Bahrun, Dewi Umandhitahim, Tumenggung Bakim, dan Raden Abdullah.

Raden Abdullah menghaturkan upeti Mekah kepada Prabu Binti Bahram. Namun upeti tersebut tidak langsung diserahkan, akan tetapi diletakkan di alun-alun. Keterlambatan 
upeti Mekah mengakibatkan kemarahan Prabu Binti Bahram. Ia minta salah satu putera Mekah agar maju ke hadapan raja dan akan dibanting. Majulah Amir Ambyah sebagai wakil Mekah. Dengan kesaktian Aji Gora Swara yang dimiliki, Prabu Binti Bahram tidak kuat mengangkat Amir. Semua hadirin tercengang, Dewi Umandhitahim yang merupakan putri dari Prabu Binti Bahram jatuh hati kepada Amir Ambyah.

Diceritakan bahwa Umar Maya dan Maktal pura-pura menjadi hantu penjaga upeti Mekah di alun-alun. Ia mau menyerahkan kepada siapa saja yang mampu mengalahkannya. Prajurit Yahman tidak mampu menandingi, Prabu Binti Bahram sendiri kalah oleh Umar. Akhirnya setelah diberi penjelasan oleh Amir, Prabu Binti Bahram mengaku kalah dan menghentikan kewajiban Mekah untuk menyerahkan upeti kepada Yahman. Ia takluk kepada Amir dan masuk agama Islam. Dewi Umandhitahim yang jatuh hati kepada Amir Ambyah mengadakan sayembara. Barang siapa yang kuat menarik busur pusaka Yahman berhak untuk meminangnya. Sebetulnya sayembara ini hanya kedok dan sudah diatur sedemikian rupa oleh Dewi Umandhitahim, dengan harapan sayembara dimenangkan oleh Amir Ambyah.

Peserta yang maju, dilempar batu timpuri oleh Dewi Umandhitahim sehingga langsung pingsan. Amir mengetahui hal ini, sehingga sewaktu Raden Tohkaran maju, dengan diam-diam dibantu oleh Amir Ambyah sehingga berhasil memenangkan dan berhak meminangnya. Para peserta tidak puas, mereka mengamuk tetapi dapat dihalau oleh Maktal dan Umarmaya.

b. Jejer VII: Negara Mekah

Tokoh : Adipati Abdulmuntalib, Patih Tambi Jumiril, Raden Abdulah, Raden Amir Ambyah, Umar Maya dan Raden Abas.

Amir Ambyah dan rombongan sampai ke Mekah melaporkan segala peristiwa yang dialaminya. Di luar, Raden Hoksam menantang Raden Amir Ambyah untuk berkelahi. Raden Hoksam tewas, Amir kembali ke dalam pertemuan dan merayakan kemenangan.

\section{Fungsi Karawitan Pada Pertunjukan Wayang Golek Menak}

Wayang Golek Menak dapat dikategorikan sebagai drama teater, karena di dalamnya terdapat beberapa unsur seni lain. Unsur seni lain tersebut adalah seni rupa, seni drama, seni sastra, seni tari dan seni musik (karawitan). Unsur seni rupa terdapat pada bentuk dan busana boneka wayang, unsur drama terdapat pada pengadegan atau karakter masing-masing tokoh maupun suasana adegan. Unsur tari terdapat pada gerak wayang, dan hampir keseluruhan gerak wayang mengacu pada gerak beksan tari Yogyakarta. Unsur seni musik dalam pertunjukan wayang Golek Menak adalah karawitan.

Penyajian Wayang Kulit Purwa atau Wayang Golek Menak, baik semalam suntuk maupun pakeliran padat atau ringkas tidak terlepas dari berbagai suasana dalam setiap adegan. Unsur-unsur pendukung suasana tersebut di antaranya vokal dalang (sulukan), dialog (antawecana), narasi (pocapan atau janturan), teknik gerak wayang, dan iringan pakeliran (Supriyono, 2007: 22). Menciptakan tata musik untuk memenuhi perwatakan pada bagian atau adegan yang diperlukan tidak mudah. Si petugas (pengrawit) harus menghayati juga jalan ceritanya, sebab iringan musik maupun gending tentunya tidak sama menampilkan watak kejiwaannya, ada musik yang menampilkan suasana gembira, sedih, maupun suasana roman. Pemilihan gending ditentukan berdasarkan hubungan rasa gending dengan suasana adegan misalnya agung, gembira, sedih, prenès, lucu (gecul), marah (sereng), dan sebagainya. Penentuan gending dilakukan oleh dalang yang merupakan sutradara dalam pertunjukan Wayang Golek Menak. Hal tersebut bertujuan agar tercapai suasana serta dramatik yang diinginkan. Pemilihan gending berikutnya juga ditentukan berdasarkan hubungan karakter gending dengan karakter tokoh. Fungsi karawitan dalam hal ini untuk menegaskan karakter tokoh dalam adegan tersebut, antara lain tokoh gagah, alusan, putri dan tokoh punakawan (gecul). Sebagai iringan, musik atau karawitan merupakan hiasan (ilustrasi) terpenting dari pada kebutuhan yang lain, misalnya tata panggung, tata busana yang sifatnya mati tanpa kejutan. Tata musik jelas akan menampilkan suasana berbeda-beda sesuai dengan adegan. 
Unsur tari dalam wayang golek Menak terlihat pada setiap gerakan wayang, yaitu setiap tokoh wayang keluar dari sisi kanan maupun sisi kiri dipastikan wayang selalu menggunakan gerak tari. Gerak dalam Wayang Golek Menak dipengaruhi oleh tari gaya Yogyakarta. Selain itu juga dapat dilihat dalam adegan perang. Dalam adegan perang, sebelum wayang melakukan perkelahian sering disajikan adegan ajon-ajon/majeng beksan, yaitu gerak tari yang dilakukan oleh dua tokoh wayang yang akan berkelahi. Jadi dalam hal ini fungsi karawitan sebagai penegas gerak wayang.

Secara instrumentasi, kendang sangat berperan penting, karena kendang sebagai pamurba atau penentu jalannya irama atau laya gending. Irama atau laya merupakan salah satu penentu keberhasilan alur pertunjukan wayang tersebut. Laya gending dalam pertunjukan wayang biasanya cenderung lebih seseg dari pada laya gending dalam karawitan yang berdiri sendiri. Selain itu kendang juga bertugas sebagai penegas gerak-gerak wayang dan menuntun dalang untuk menentukan vokabuler gerak wayang.

Garis besar fungsi karawitan dalam pakeliran adalah sebagai iringan yang tentunya mempunyai kedudukan yang berbeda dengan karawitan yang berdiri sendiri. Garap iringan juga terikat oleh kehendak ki dalang. Seorang pengrawit harus mengikuti struktur gending yang telah ditentukan oleh dalang. Kebutuhan dalam iringan pakeliran adalah dapat mendukung atau memantabkan sajian pakeliran. Karawitan mempunyai peranan yang sangat besar dalam menentukan berhasilnya suatu sajian pakeliran. Salah satu fungsi karawitan iringan dalam pakeliran adalah memberi tekanan suasana dan karakteristik. Sedangkan bentuk lagu kebanyakan dibawakan secara instrumentalia (gendhingan) dan lagu disesuaikan pula dengan keadaan waktu, sehingga terasa adanya jalinan suasana antara waktu dan lagu.

\section{Pembagian Urutan Pathet Berdasarkan Pembabakan dan Adegan}

Wayang Golek Menak disajikan dalam waktu semalam suntuk. Jika diperhatikan struktur pengadegannya, tidak jauh berbeda dengan struktur pengadegan Wayang Kulit Purwa. Dalam pergelaran wayang pembabakan dibagi menjadi tiga bagian yang terbingkai dalam pathet, yaitu pathet nem, pathet sanga, dan pathet manyura. Pathet dalam hal ini berfungsi sebagai pembagi durasi waktu dalam pertunjukan wayang semalam suntuk.

Penyajian babak pertama pathet nem diawali dari pukul 09.00 sampai pukul 24.00. Penyajian babak kedua pathet sanga diawali dari pukul 24.00 sampai 03.00. Untuk babak ketiga pathet manyura diawali dari pukul 03.00 sampai selesai, dengan kata lain setiap babak disajikan dalam waktu tiga jam (Mudjanattistomo, 1977:161). Pergelaran wayang diakhiri dengan pathet galong yang merupakan pathet bagian atau masuk dalam pathet manyura. Disebut bagian atau masuk dalam pathet manyura, karena gending dalam pathet galong menggunakan céngkok-céngkok gendèran dan céngkok-céngkok sindhènan wilayah pathet manyura.

Pembagian pembabakan, adegan, dan jejer juga banyak mengacu pada Wayang Kulit Purwa Gaya Yogyakarta. Istilah jejer dalam tradisi Yogyakarta adalah penggambaran suatu tempat atau negara yang diiringi dengan gending tertentu. Dalang memberikan narasi pada adegan tersebut saat gending sirep. Sebelum pertunjukan dimulai didahului alunan gending-gending talu yang dalam tradisi gaya Yogyakarta menggunakan gendinggending pathet sanga.

Pergelaran wayang kulit purwa terdiri dari tujuh jejeran yang terbingkai dalam pathet nem, sanga, dan manyura. Jejer pertama, kedua dan ketiga masuk dalam pathet nem. Adegan khusus gara-gara, jejer keempat, dan jejer kelima masuk pathet sanga. Jejer keenam, dan ketujuh masuk pathet manyura. Pembagian jejer dalam Wayang Kulit Purwa tersebut juga berlaku dalam pertunjukan Wayang Golek Menak. Pembabakan dan pengadegan dalam Wayang Golek Menak mengacu pada pembabakan

Tabel 1. Pembagian babak dan adegan Wayang Golek Menak Yogyakarta.

\begin{tabular}{lll}
\hline Pathet & \multicolumn{1}{c}{ Adegan } \\
\hline Nem & 1. Jejer kapisan & : Adegan Kedhaton \\
& 2. Jejer kaping kalih & : Perang Simpang \\
Sanga & 3. Jejer kaping tiga & : Perang Gagal \\
& 1. Gara-Gara & \\
& 2. Jejer kaping sekawan: Perang Bégal \\
& 3. Jejer kaping gangsal : Perang Tanggung \\
Manyura & 1. Jejer kaping nem & : Perang Tandang \\
& 2. Jejer kaping pitu & : Perang Brubuh \\
& 3. Golèkan & \\
4. Tanceb Kayon & \\
\hline
\end{tabular}


dan pengadegan dalam Wayang Kulit Purwa. Pembabakan dan pengadegan tersebut dapat dilihat pada tabel 1.

Instrumen gamelan yang digunakan dalam Wayang Golek Menak hanya berlaras sléndro. Gending-gending yang digunakan adalah bentuk gending Candra, Laheha, Ladrang, Ketawang, Ayakayak, Srepegan, Playon, Sampak, Lancaran dan
Bubaran. Pada dasarnya terdapat beberapa alasan pemilihan penggunakan gending tertentu untuk keperluan karawitan pakeliran, antara lain: (1) Hubungan nama gending dengan adegan/tokoh; (2) Hubungan antara karakter tokoh wayang dengan karakter gending; (3) Sumber daya manusia (pengrawit) atau kemampuan pengrawit; (4) Selera dalang (Supanggah, 1999:136).

Tabel 2. Penggunaan gending pada setiap jejer maupun adegan.

\begin{tabular}{|c|c|c|c|}
\hline Adegan & Gending & Keterangan & $\begin{array}{c}\text { Rasa } \\
\text { Gending }\end{array}$ \\
\hline Jejer Kapisan & $\begin{array}{l}\text { Ketawang gending kabor topèng } \\
\text { minggah ladrang kabor laras } \\
\text { sléndro pathet nem }\end{array}$ & Gending baku & Regu \\
\hline Kondur Kedhaton & $\begin{array}{l}\text { Ayak-ayak kembang jeruk laras } \\
\text { sléndro pathet nem }\end{array}$ & Gending baku & Regu \\
\hline Paséban Njawi & $\begin{array}{l}\text { Ladrang gègèr sakutha laras } \\
\text { sléndro pathet nem }\end{array}$ & Tidak baku/alternatif & Gagah \\
\hline Budhalan (Lurugan) & $\begin{array}{l}\text { Lancaran gagak sétra laras sléndro } \\
\text { pathet nem }\end{array}$ & Tidak baku/alternatif & Gagah \\
\hline Perang Ampyak & $\begin{array}{l}\text { Playon kembang jeruk laras } \\
\text { sléndro pathet nem }\end{array}$ & Gending baku & Sigrak \\
\hline Jejer Kaping Kalih & $\begin{array}{l}\text { Ladrang wirangrong laras sléndro } \\
\text { pathet nem }\end{array}$ & Tidak baku/alternatif & Gagah \\
\hline Perang Simpang & $\begin{array}{l}\text { Playon kembang jeruk laras } \\
\text { sléndro pathet nem }\end{array}$ & Gending baku & Sigrak \\
\hline Jejer Kaping Tiga & $\begin{array}{l}\text { Gending bondhèt laras sléndro } \\
\text { pathet nem }\end{array}$ & Tidak baku/alternatif & Prenès \\
\hline Perang Gagal & $\begin{array}{l}\text { Playon kembang jeruk laras } \\
\text { sléndro pathet nem }\end{array}$ & Gending baku & Sigrak \\
\hline Peralihan & Lagon pathet sanga & Dilagukan setelah suwuk Playon & Lugu/Wantah \\
\hline Gara-Gara & $\begin{array}{l}\text { Ayak-ayak kembang jeruk laras } \\
\text { sléndro pathet sanga }\end{array}$ & Gending baku & Regu \\
\hline Jejer Kaping Sekawan & $\begin{array}{l}\text { Ladrang pangkur laras sléndro } \\
\text { pathet sanga }\end{array}$ & Tidak baku/alternatif & Regu \\
\hline Perang Bégal & $\begin{array}{l}\text { Playon kembang jeruk laras } \\
\text { sléndro pathet sanga }\end{array}$ & Gending baku & Sigrak \\
\hline Jejer Kaping Gangsal & $\begin{array}{l}\text { Ladrang semingin laras sléndro } \\
\text { pathet sanga }\end{array}$ & Tidak baku/alternatif & Gagah \\
\hline Peralihan & Lagon manyura wetah & Dilagukan setelah suwuk Playon & Lugu/Wantah \\
\hline Perang Tanggung & $\begin{array}{l}\text { Playon gegot laras sléndro pathet } \\
\text { manyura }\end{array}$ & Gending baku & Sigrak \\
\hline Jejer Kaping Nem & $\begin{array}{l}\text { Ladrang sumirat laras sléndro } \\
\text { pathet manyura }\end{array}$ & Tidak baku/alternatif & Sigrak \\
\hline Perang Tandang & $\begin{array}{l}\text { Playon gégot laras sléndro pathet } \\
\text { manyura }\end{array}$ & Gending baku & Sigrak \\
\hline Perang Brubuh & $\begin{array}{l}\text { Playon gambuh, sorodatan laras } \\
\text { sléndro pathet manyura }\end{array}$ & Gending baku & Sigrak \\
\hline Jejer Kaping Pitu & $\begin{array}{l}\text { Ayak-ayak wayang purwa laras } \\
\text { sléndro pathet manyura }\end{array}$ & Tidak baku/alternatif & Regu \\
\hline
\end{tabular}


Gending yang digunakan dalam pertunjukan Wayang Golek Menak berfungsi untuk mendukung suasana bangunan lakon, yang sering disebut sebagai gending baku. Ada beberapa gending baku yang digunakan di samping juga digunakan alternatif gending yang biasanya digunakan dalam jejer II, jejer III, jejer VII, geculan, dan digunakan dalam adegan ajon-ajon atau majeng beksan.

Pemilihan alternatif gending menggunakan sasmita, isyarat atau kode, berupa wangsalan yang kemudian diikuti tanda dhodhogan atau keprakan untuk memulai buka gending. Bentuk sasmita tersebut misalnya "Ebahing para nararya karya nggè- gèraken wadya sakutha" (untuk meminta ladrang Gègèr Sakutha). Beberapa gending yang dibakukan dalam Wayang Golek Menak adalah Gending Kabor Topèng Laras Sléndro Pathet Nem, Playon Kembang Jeruk Laras Sléndro Pathet Nem/ Sanga, Playon Gégot Laras Sléndro Pathet Manyura, Playon Gambuh/Sorodatan Laras Sléndro Pathet Galong, Sampak Gunturan, dan Ayak-ayak Kembang Jeruk Laras Sléndro Pathet Nem dan Sanga. Gending-gending tersebut diaplikasikan sesuai kegunaan dalam masing-masing adegan. Gending Kabor Topèng digunakan untuk jejer pertama. Kemudian ayak-ayak Kembang Jeruk Pathet Nem digunakan untuk kondhur kedhaton, sedangkan ayak-ayak Kembang Jeruk Pathet Sanga digunakan untuk gara-gara. Playon digunakan pada situasi netral, tenang dan sampak digunakan dalam situasi kaget, tergesa-gesa, marah, keras dan sebagainya. Penggunaan gending pada setiap jejer dan adegan dalam pergelaran Wayang Golek Menak Yogyakarta dapat dilihat pada tabel 2 .

Sejarah penggunaan gending Kabor Topèng dalam Wayang Golek Menak berawal atau mengacu pada karawitan yang digunakan dalam Wayang Topèng gaya Yogyakarta. Selain itu gerak wayang juga mengacu pada gerak Wayang Topèng. Dikatakan mengacu karena Wayang Topèng di Daerah Istimewa Yogyakarta lahir lebih dahulu dibanding kehadiran Wayang Golek Menak. Wayang Topèng sudah ada sekitar tahun 1850 M, demikian pernyataan Murgiyanto yang dikutip oleh Sumaryono (2009: 16). Dalam penyajian Wayang Topèng, gending untuk jejer kapisan selalu dimainkan Gending Kabor Topèng Laras Sléndro Pathet Nem Kendhangan Lahela (Sumaryono, 2009: 24-25).
Jika gending Kabor Topèng mengacu pada Wayang Topèng maka playon maupun sampak terpengaruh oleh Wayang Golek Menak Kutoarjo atau Kebumen. Playon Kembang Jeruk laras Sléndro pathet Nem dan Playon Kembang Jeruk laras Sléndro pathet Sanga, Playon Gégot laras Sléndro pathet Manyura dan Sampak Gunturan terpengaruh playon dari Kebumen dan Kutoarjo. Karena pada masa itu belum ada alat untuk mendokumentasikan, hanya mengandalkan pendengaran dan ingatan, maka playon dan sampak yang digunakan di Yogyakarta sedikit berbeda dengan yang digunakan di Kebumen atau Kutoarjo. Rupa-rupanya pada masa itu, Ki Widiprayitna lebih menyukai iringan karawitan yang digunakan dalam Wayang Golek Menak dari Kutoarjo.

Adapun gending Ayak-Ayak Kembang Jeruk, diciptakan sendiri oleh Ki Sukarno berdasar atau mengacu pada Playon Kembang Jeruk. Ayak-Ayak tersebut sering digunakan Ki Sukarno untuk adegan kondhur kedhaton (pathet nem) dan adegan gara-gara (pathet sanga).

\section{Gending-Gending dalam Iringan Karawitan Wayang Golek Menak Yogyakarta}

Pembabakan atau pembagian waktu dalam pertunjukan Wayang Golek Menak Yogyakarta terbingkai dalam suatu pathet yang terdiri dari pahtet Nem, Sanga, dan Manyura. Setiap babak menggunakan beberapa gending yang disesuaikan dengan masing-masing pathet. Adapun gendinggending yang digunakan Ki Sukarno sebagai iringan pergelaran Wayang Golek Menak Yogyakarta adalah sebagai berikut.

a. Ketawang gending kabor laras sléndro pathet nem

$$
\begin{aligned}
& \text { Buka: . } 5 \begin{array}{lllllllllllllll} 
& 6 & \text { i } & 5 & 3 & 2 & 3 & 6 & 5 & 3 & 2 & 1 & 6 & 3 & \text { (5) }
\end{array} \\
& \begin{array}{llllllllllllllll}
2 & 3 & 2 & 1 & 1 & 1 & 2 & 3 & 6 & 5 & 3 & 2 & 1 & 6 & 3 & 5
\end{array} \\
& \text {. } \begin{array}{rrrrrrrrrrrrrrr}
5 & 6 & + & 5 & 3 & 2 & 3 & 6 & 5 & 3 & 2 & 1 & 6 & 3 & 5
\end{array} \\
& \text { Minggah ladrang } \quad 5 \quad 653
\end{aligned}
$$

b. Ladrang kabor laras sléndro pathet nem

$$
\begin{array}{llllllllllllllll}
5 & 6 & 5 & 2 & 5 & 6 & 5 & 3 & 5 & 6 & 5 & 2 & 5 & 6 & 5 & 3 \\
5 & 6 & 5 & 2 & 5 & 6 & 5 & 3 & 5 & 5 & 6 & i & 2 & 1 & 6 & 5 \\
6 & 5 & 6 & i & 2 & 1 & 6 & 5 & 6 & 5 & 6 & i & 2 & 1 & 6 & 5 \\
6 & 5 & 6 & i & 2 & 1 & 6 & 5 & 6 & 6 & 3 & 2 & 5 & 6 & 5 & 3
\end{array}
$$


Ketawang Gending Kabor Topèng minggah Ladrang Kabor Laras Sléndro Pathet Nem termasuk gending baku dalam penyajian Wayang Golek Menak Yogyakarta. Gending tersebut digunakan untuk jejer pertama. Buka dilakukan oleh instrumen gendèr setelah mendapat isyarat dari dalang berupa dhodhogan kotak. Irama I disajikan dalam dua gatra kenong pertama setelah gong buka gending Kabor Topèng, dilanjutkan irama II atau irama dados dengan garap lirihan atau alusan, disajikan berulang-ulang. Garap sirep disajikan setelah kenong pertama, digunakan dalang untuk melakukan janturan. Setelah janturan selesai, dalang ndhodhog kotak tepat pada tabuhan kethuk pertama. Secara perlahan tempo atau laya semakin seseg atau cepat hingga kenong pertama, setelah itu disajikan dalam irama I dan minggah ke ladrang.

Ladrang disajikan irama I, digunakan untuk mengiringi tokoh raja yang ditampilkan dengan gerak jogèdan/kiprah ('menari'). Ladrang disajikan dengan garap soran. Laya dalam ladrang Kabor disesuaikan dengan karakter tokoh raja. Jika tokoh berkarakter halus, laya yang digunakan sedikit lambat. Tokoh berkarakter gagah (kasar), laya yang digunakan seseg atau cepat.

c. Ayak-ayak kembangjeruk laras sléndro pathet nem Buka: $5 \quad 555$ $\begin{array}{llllllllllllllll}6 & 5 & 6 & 5 & 6 & 5 & 6 & \overline{5} & 2 & 1 & 2 & 1 & 2 & 3 & 5 & 6\end{array}$ $\begin{array}{llllllllllllllll}1 & 2 & 1 & 6 & 1 & 2 & 1 & 6 & 3 & 3 & 6 & 5 & 6 & 3 & 1 & 2\end{array}$ $\begin{array}{llllllllllllllll}3 & 1 & 3 & 2 & 3 & 1 & 3 & 2 & 3 & 2 & 1 & 6 & 5 & 2 & 3 & 5\end{array}$ $\begin{array}{llllllllllllllll}3 & 6 & 3 & 5 & 3 & 6 & 3 & 5 & 2 & 1 & 2 & 1 & 2 & 3 & 5 & 6\end{array}$

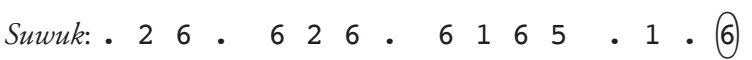

Ayak-Ayak Kembang Jeruk laras Sléndro pathet Nem termasuk gending baku digunakan untuk adegan Kondur Kedhaton. Buka gending dilakukan oleh instrumen kendang yang sebelumnya mendapat isyarat berupa dhodhogan kotak dari dalang. Gending tersebut disajikan berulang-ulang dalam irama dados laya antal. Garap sirep disajikan untuk janturan gapuran.

d. Ladrang gègèr sekutha laras sléndro pathet nem

$$
\begin{array}{rllllllllllllllll}
\text { Buka: } & \cdot & 3 & 5 & 2 & \cdot & 3 & 5 & 2 & 1 & 1 & 2 & 1 & 5 & 5 & 5 & (5) \\
& + & & & & + & & & & + & & \breve{3} & & + & & 5 \\
6 & 5 & 6 & i & 2 & 1 & 6 & 5 & 6 & 5 & 6 & i & 2 & 1 & 6 & 5
\end{array}
$$

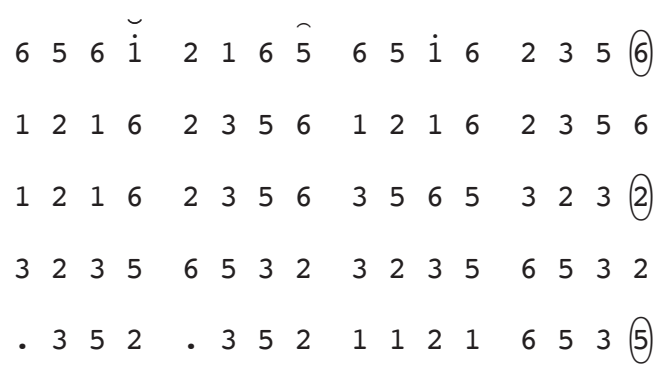

Ladrang Gègèr Sekutha digunakan untuk adegan paséban jawi, gending ini tidak termasuk dalam gending baku. Buka gending dilakukan instrumen bonang barung dan disajikan dengan garap soran irama I menggunakan kendhangan ladrang kendang kalih gaya Yogyakarta menggunakan kendang batangan (ciblon) digunakan untuk mengiringi kiprah dan keluar atau masuknya tokoh wayang. Setelah tokoh-tokoh wayang berada dalam satu adegan, laya seseg atau semakin cepat, dan kembali menggunakan kendang kalih, sampai suwuk gropak, yaitu garap suwuk irama I (tanggung) yang menggunakan tabuhan keras, gagah, dan tempo yang cepat.

e. Lancaran gagak sétra laras sléndro pathet nem

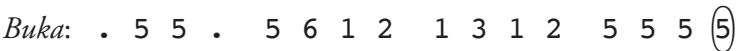

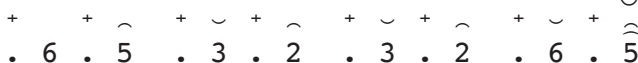

$$
\begin{aligned}
& \text {.6.5.3. } 2 \cdot 3 \cdot 2 \cdot 6 \cdot 5 \\
& \text {. } 6.1 \cdot 2 \cdot 1 \cdot 2 \cdot 1 \cdot 6 \cdot 5 \\
& \text {. } 6.1 .2 \cdot 1 \cdot 2 \cdot 1 \cdot 6 \cdot 5 \\
& \text {. } 1.6 .3 \cdot 2.3 \cdot 2.6 \text {. } 5
\end{aligned}
$$

Buka Lancaran Gagak Sétra dilakukan oleh instrumen bonang, menggunakan irama lancar dengan pola kendhangan lancaran kendang kalih dan kendang batangan yang berfungsi mengikuti vokabuler gerak wayang. Pola balungan Lancaran Gagak Sétra Laras Slendro Pathet Nem adalah lamba. Gending tersebut digunakan untuk adegan Perang Ampyak. Garap tabuhan ricikan slenthem dan demung mengacu pada balungan gending atau mbalung. Tabuhan saron menggunakan garap imbal kecegan dan peking menggunakan garap tabuhan nikeli. Garap tabuhan instrumen bonang menggunakan tabuhan gembyang minjal.

f. Gending bondhèt laras sléndro pathet nem

$\begin{array}{lrrrr}\text { Buka: } & .353 & 5653 & 2132 & 163(5) \\ & + & & + & 0 \\ \text { Dados: } & 2312 & .365 & 1653 & 2165\end{array}$




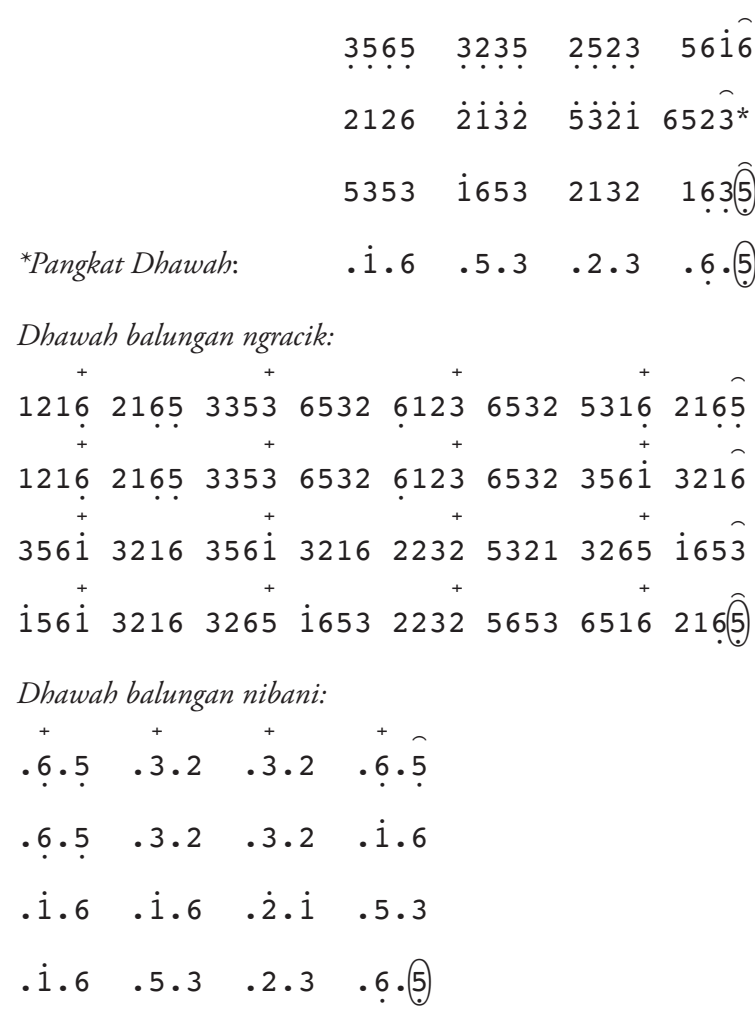

Buka Gending Bondhèt Laras Sléndro Pathet Nem, dilakukan instrumen rebab. Pada ketukan ke-8 menjelang gong buka diikuti instrumen kendang yang diakhiri tabuhan gong dan bersamaan pula dengan instrumen lainnya dengan menabuh nada 5 (lima). Penyajian gending ini disajikan dalam irama tanggung, dados, dan wiled. Penyajian irama tanggung menggunakan kendhangan Candra dan kendhangan gembyakan yang berfungsi untuk memberi tekanan pada gerak-gerak wayang. Ketika irama dados menggunakan kendang setunggal, irama dados menjelang kenong pertama, dalang ndhodhog sirep untuk janturan diikuti tempo atau laya yang semakin cepat menuju pangkat dhawah masuk irama wiled menggunakan kendang ciblon (batangan) sampai suwuk. Pada irama wiled (dhawah) tabuhan yang digunakan oleh Ki Sukarno adalah tabuhan balungan ngracik. Pada zaman kejayaan Ki Widiprayitna, setiap pergelaran wayang tidak menggunakan instrumen rebab, sehingga tabuhan ngracik pada bagian dhawah digunakan untuk mengganti melodi lagu rebab.

g. Ladrang wirangrong laras sléndro pathet nem

Buka: $\begin{array}{lllllllllllllll}5 & 6 & 5 & 3 & 2 & 1 & 6 & 5 & \cdot & 6 & \cdot & 3 & \cdot & 6 & \text {. (5) }\end{array}$

$\begin{array}{llllllllllllllll}6 & 2 & 6 & 1 & 6 & 3 & 6 & 5 & 6 & 2 & 6 & 1 & 6 & 3 & 6 & 5\end{array}$

$\begin{array}{llllllllllllllll}6 & 2 & 6 & 1 & 6 & 3 & 6 & 5 & 2 & 3 & 5 & 6 & 3 & 5 & 3 & 2\end{array}$ $\begin{array}{llllllllllllllll}5 & 6 & 5 & 3 & 2 & 1 & 6 & 5 & 2 & 3 & 5 & 6 & 3 & 5 & 2 & 3\end{array}$

$\begin{array}{lllllllllllllll}5 & 6 & 5 & 3 & 2 & 1 & 6 & 5 & \cdot 6 & & & & & & \end{array}$

Ladrang Wirangrong digunakan untuk adegan jejer ketiga, tetapi gemding ini tidak termasuk dalam gending baku. Buka dilakukan oleh instrumen bonang barung. Satu ulihan atau satu gongan gending ladrang terdapat 32 tabuhan balungan. Ladrang Wirangrong disajikan dalam irama I (tanggung) dan irama II (dados) kendhangan ladrang kendang kalih gaya Yogyakarta. Irama I (tanggung) disajikan berulang-ulang menggunakan garap soran, sedangkan irama II (dados) disajikan dengan garap lirihan/alusan yang disertai dengan garap sirep untuk janturan. Setelah janturan selesai, kembali ke irama I (tanggung), laya naik atau semakin cepat dan suwuk gropak.

h. Playon kembang jeruk laras sléndro pathet nem Buka kendang:

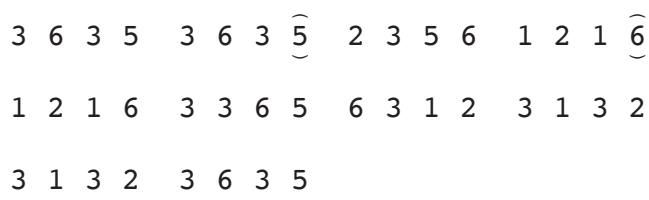

Playon Kembang Jeruk Laras Sléndro Pathet Nem digunakan untuk adegan-adegan dalam pathet nem, di antaranya adalah perang simpang/ simpangan yang merupakan rangkain jejer kaping kalih. Dalam perang tersebut terdapat adegan ajon-ajon atau majeng beksa, yaitu gerak tarian yang dilakukan dua tokoh wayang sebelum melakukan perang. Gending yang digunakan berbentuk ladrang atau ketawang dan disesuaikan dengan karakter tokoh wayang. Selain itu, Playon Kembang Jeruk Laras Sléndro Pathet Nem tersebut digunakan untuk adegan Perang Gagal. Buka gending dilakukan oleh instrumen kendang yang sebelumnya mendapat isyarat berupa dhodhogan kotak dari dalang. Playon KembangJeruk memiliki 40 tabuhan balungan, menggunakan sajian irama I (tanggung). Laya yang disajikan menurut kebutuhan suasana adegan wayang.

i. Sampak Gunturan Laras Sléndro Patet Nem

$$
\begin{array}{llllllll}
6 & 6 & 6 & 6 & 6 & 6 & 6 & 2
\end{array}
$$

Suwuk: $\quad 6662$ 
Sampak Gunturan digunakan untuk menggambarkan suasana adegan terkejut, marah, dan kalah atau kematian dalam perang.

j. Ayak-ayak kembang jeruk laras sléndro pathet sanga

$$
\begin{aligned}
& \text { Buka kendang: } \\
& \begin{array}{llllllllllllllllll}
2 & 5 & 2 & 3 & 2 & 5 & 2 & 3 & 1 & 6 & 1 & 6 & 2 & 1 & 6 & 5 \\
6 & 1 & 6 & 5 & 6 & 1 & 6 & 5 & 2 & 2 & 5 & 3 & 5 & 2 & 3 & 1 \\
2 & 6 & 2 & 1 & 2 & 6 & 2 & 1 & 2 & 1 & 6 & 5 & 3 & 1 & 2 & 3 \\
2 & 5 & 2 & 3 & 2 & 5 & 2 & 3 & 1 & 6 & 1 & 6 & 2 & 1 & 6 & 5
\end{array}
\end{aligned}
$$

k. Playon kembang jeruk laras sléndro pathet sanga

$$
\begin{array}{llllllllllllllll}
2 & 5 & 2 & 3 & 2 & 5 & 2 & \overline{3} & 1 & 2 & 3 & 5 & 6 & 1 & 6 & 5 \\
6 & 1 & 6 & 5 & 2 & 2 & 5 & 3 & 5 & 3 & 2 & 1 & 2 & 6 & 2 & 1 \\
2 & 6 & 2 & 1 & 2 & 5 & 2 & 3 & & & & & & & &
\end{array}
$$

1. Sampak gunturan laras sléndro pathet sanga

$$
\begin{array}{lllllllll} 
& 5 & 5 & 5 & 5 & 5 & 5 & 5 & 1 \\
\text { Suwuk: } & & & & & 5 & 5 & 5 & 1
\end{array}
$$

Gending Ayak-ayak KembangJeruk, Playon Kembang Jeruk dan Sampak Gunturan disajikan secara berurutan (midley) dan digunakan untuk mengirirngi adegan Gara-Gara. Buka gending dilakukan oleh instrumen kendang yang sebelumnya mendapat isyarat berupa dhodhogan kotak dari dalang. Pada ulihan pertama Ayak-ayak Kembang Jeruk, terdapat 64 tabuhan balungan, kemudian dalam ulihan yang kedua dan seterusnya, terdapat 48 tabuhan balungan. Gending Ayak-ayak disajikan dalam irama I menggunakan laya antal dengan garap lirihan atau alusan dan disajikan berulangulang menurut kebutuhan sampai bagian dhawah dilanjutkan ke Playon Kembang Jeruk Laras Sléndro Pathet Sanga. Penyajian Playon Kembang Jeruk dalam irama I dengan laya antal hingga kendang mendapat isyarat dari dalang dan gending berubah menjadi Sampak Gunturan sampai suwuk. Fungsi playon selain merupakan rangkaian gending adegan gara-gara, juga digunakan dalam Perang Bégal dan Perang Tanggung.

$\mathrm{m}$. Ladrang pangkur laras sléndro pathet sanga

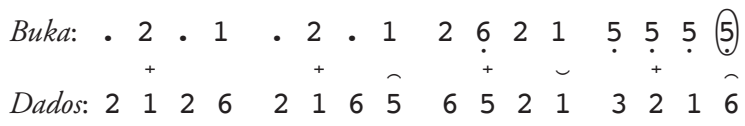

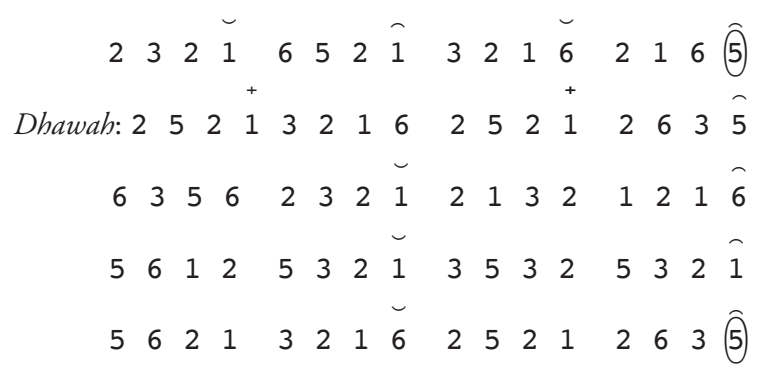

Buka Gending Pangkur dilakukan instrumen rebab. Pada ketukan ke-9 menjelang gong buka diikuti kendang ladrang yang diakhiri tabuhan gong dan bersamaan dengan instrumen lainnya dengan menabuh nada 5 (Purnama, 2011:57)). Penyajian gending ini disajikan dalam irama I, II, dan III. Pada saat penyajian irama I menggunakan kendhangan ladrang irama I kendang kalih dan kendhangan gembyakan yang berfungsi untuk memberi tekanan pada gerakgerak wayang. Ketika irama II menggunakan kendang kalih. Pada irama III menggunakan kendang ciblon (batangan). Ladrang Pangkur dalam penyajiannya diselingi dengan sirep dalam irama III, kemudian pada kethuk ke 6 dalang ndhodhog kotak, laya seseg dan suwuk.

n. Ladrang semingin laras sléndro pathet sanga

$$
\begin{aligned}
& \text { Buka: } \quad \begin{array}{lllllllllllllll}
5 & \text { • } & 5 & 6 & 1 & 6 & 5 & 6 & 1 & 2 & 1 & 5 & 5 & 5 & (5)
\end{array} \\
& \text { Irama I: } \begin{array}{llllllllllllllll}
6 & 5 & 3 & 5 & 3 & 2 & 3 & 5 & 2 & 1 & 2 & 6 & 2 & 1 & 6 & 5
\end{array} \\
& \begin{array}{llllllllllllllll}
2 & 1 & 2 & 6 & 2 & 1 & 6 & 5 & 2 & 3 & 1 & 2 & 3 & 5 & 3 & 2
\end{array} \\
& \begin{array}{llllllllllllllll}
+ & 2 & 3 & 2 & 3 & 5 & 3 & 2 & 5 & 6 & 1 & 6 & 5 & 3 & 2 & 1
\end{array} \\
& \begin{array}{llllllllllllllll}
5 & 6 & 1 & 6 & 5 & 3 & 2 & 1 & 2 & 3 & 2 & 1 & 6 & 5 & 3 & \text { (5) }
\end{array}
\end{aligned}
$$

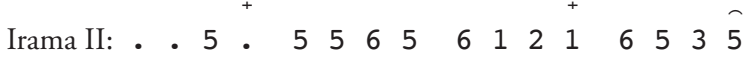

$$
\begin{aligned}
& .2 \cdot 1 \cdot 2 \cdot 6 \cdot 2 \cdot 1 \cdot 6 \cdot 5 \\
& .2 \cdot 1 \cdot 2 \cdot 6 \cdot 2 \cdot 1 \cdot 6 \cdot 5 \\
& \begin{array}{llllllllllllllll}
3 & 2 & . & 3 & 1 & 2 & 3 & 2 & 3 & 5 & 6 & 5 & 3 & 2 & 1 & 2
\end{array} \\
& \text {. } 62 \text {. } 6212235653212 \\
& \begin{array}{llllllllllllllll}
3 & 5 & . & 6 & 1 & 2 & 1 & 6 & 5 & 1 & 5 & 2 & 5 & 3 & 2 & 1
\end{array} \\
& \begin{array}{llllllllllllllll}
2 & 3 & 5 & 6 & 1 & 2 & 1 & 6 & 5 & 1 & 5 & 2 & 5 & 3 & 2 & 1
\end{array}
\end{aligned}
$$

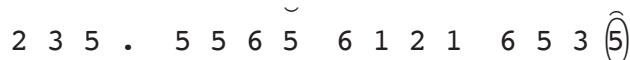

Ladrang Semingin Laras Sléndro Pathet Sanga digunakan untuk adegan jejer gangsal, namun gending ini tidak termasuk dalam gending baku. Buka gending dilakukan oleh instrumen bonang barung. Dalam satu ulihan atau satu gongan bentuk gending ladrang terdapat 
32 tabuhan balungan, tetapi dalam penyajian irama II, Ladrang Semingin menggunakan tabuhan balungan ngracik, jadi dalam satu ulihan atau satu gongan bentuk gending ladrang Semingin irama II terdapat 64 tabuhan balungan. Gending ini disajikan dalam irama I dan irama II kendhangan ladrang kendang kalih gaya Yogyakarta, berulang-ulang dengan garap soran. Kendang batangan digunakan untuk mengiringi kiprah dan keluar tokoh wayang. Setelah tokoh-tokoh wayang berada dalam satu adegan, laya seseg atau semakin cepat dan kembali menggunakan kendang kalih, sampai suwnk gropak, yaitu tabuhan keras, tempo cepat.

o. Playon gégot laras sléndro pathet manyura Buka kendang: - 22 $\begin{array}{llllllllllllllll}3 & 6 & 3 & 5 & 3 & 6 & 3 & 2 & 3 & 6 & 3 & 5 & 3 & 6 & 3 & 2\end{array}$ $\begin{array}{llllllllllllllll}6 & 6 & 1 & 2 & 3 & 2 & 1 & 6 & 5 & 6 & 1 & 2 & 3 & 2 & 1 & 6\end{array}$ $\begin{array}{llllllllllllllll}5 & 3 & 5 & 2 & 5 & 3 & 5 & 6 & 3 & 2 & 3 & 5 & 3 & 6 & 3 & 2\end{array}$ Suwuk: $\begin{array}{llllll}1 & 1 & 3 & 2 & 1 & 6\end{array}$

Playon Gégot digunakan dalam Perang Tandang. Selain itu Playon Gégot juga digunakan untuk adegan jejer pitu dengan garap sirep. Buka gending dilakukan oleh instrumen kendang yang sebelumnya mendapat isyarat berupa dhodhogan kotak dari dalang. Tidak berbeda dengan Playon Kembang Jeruk, laya dalam Playon Gégot disajikan menurut kebutuhan suasana adegan wayang.

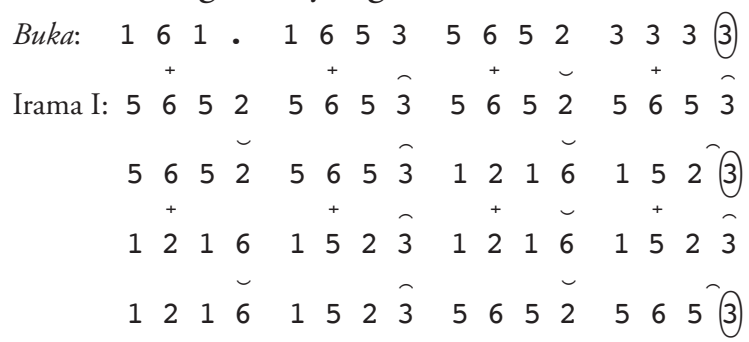

p. Ladrang sumirat laras sléndro pathet manyura

Ladrang Sumirat digunakan untuk adegan jejer enem, namun tidak termasuk dalam gending baku. Buka gending tersebut dilakukan oleh instrumen bonang barung, disajikan dalam irama I kendhangan ladrang kendang kalih gaya Yogyakarta, berulang-ulang dengan garap soran. Kendang batangan yang digunakan untuk mengiringi kiprah dan keluarnya tokoh wayang. Setelah tokoh-tokoh wayang berada dalam satu adegan, laya maju, seseg atau semakin cepat dan kembali menggunakan kendang kalih, sampai suwuk antal.

q. Playon gambuh laras sléndro pathet manyura

Buka kendang:

$\begin{array}{llllllllllllllll}1 & 3 & 1 & 3 & 1 & 6 & 5 & \overline{3} & 6 & 5 & 3 & 5 & 6 & 1 & 5 & 6\end{array}$

$\begin{array}{llllllllllllllll}2 & 6 & 2 & 6 & 3 & 2 & 1 & 6 & 3 & 5 & 6 & 1 & 6 & 5 & 2 & 3\end{array}$

Suwuk: $\quad \begin{array}{llllll}1 & 3 & 1 & 6 & 5 & 3\end{array}$

$\begin{array}{llllll}2 & 6 & 1 & 6 & 5 & 3\end{array}$

Buka gending dilakukan oleh instrumen kendang yang sebelumnya mendapat isyarat berupa dhodhogan kotak dari dalang. Tidak berbeda dengan playon-playon sebelumnya, laya dalam Playon Gambuh disajikan menurut kebutuhan suasana adegan wayang. Playon Gambuh biasanya cenderung menggunakan laya seseg. Hal tersebut dikarenakan Playon Gambuh digunakan dalam adegan klimak dari cerita semalam suntuk. Playon Gambuh disajikan dalam pathet galong, yaitu pathet yang merupakan bagian dari pathet manyura dan merupakan akhir dari pathet manyura. Playon Gambuh digunakan dalam adegan Perang Brubuh.

\section{Penutup}

Garap iringan karawitan pergelaran Wayang Golek Menak yang disajikan Ki Sukarno tidak jauh berbeda dengan garap iringan karawitan dalam pakeliran Wayang Kulit Purwa Gaya Yogyakarta. Garap iringan karawitan pergelaran Wayang Golek Menak seperti ciri garap pakeliran pada umumnya yaitu menggunakan kendang wayang, saron imbal nacah kinthilan/nyeceg, garap sirep, dan garap irama, yang membedakan adalah pada sajian irama. Gerak boneka wayang dalam Wayang Golek Menak selalu menggunakan tarian, sehingga sajian irama tidak seseg seperti pada Wayang Kulit dan cenderung mengacu pada garap irama karawitan tari.

Karawitan merupakan unsur penunjang keberhasilan pertunjukkan Wayang Golek Menak Yogyakarta. Fungsi iringan karawitan tidak hanya sekedar sebagai ilustrasi, melainkan juga sebagai penegas vokabuler gerak-gerak wayang, mengingat dalam pergelaran Wayang Golek Menak gerakgerak wayang terpengaruh gerak tari. Gerak wayang dengan iringan karawitan demikian itu berfungsi menghidupkan karakter wayang. Selain 
itu karawitan juga mendukung suasana adegan. Sebagai contoh gending playon, sampak, lancaran digunakan untuk adegan perang, gending dengan rasa sedih digunakan untuk adegan sedih, dan sebagainya. Pemilihan gending juga berhubungan dengan karakter masing-masing tokoh wayang, misalnya gending dengan karakter gagah digunakan untuk adegan tokoh gagah, gending dengan karakter alus (prenès) digunakan untuk adegan alus atau putri, gending dengan karakter gecul digunakan untuk adegan gecul.

\section{Kepustakaan}

\section{a. Acuan}

Harpawati, Tatik. 2009. "Transformasi Cerita Serat Menak Dalam Pertunjukan Wayang Golek Menak". dalam GELAR.

Istanti, Kun Zachrun. 2013. "Wayang Golek Menak sebagai Media Dakwah Islam", dalam Humaniora.

Murtiyoso, Bambang, dkk. 2004. Pertumbuhan dan Perkembangan Seni Pertunjukan Wayang. Surakarta: Citra Etnika Surakarta.

Mudjanattistomo. R.M., dkk. 1977. Pedhalangan Ngayogyakarta Jilid 1. Yogyakarta: Yayasan Habirandha Ngayogyakarta.

Purnama, Bayu. 2011. "Penyajian GendingGending Tradisi: Gending Taliwangsa, Kiyagong Ririh, Purwa Gilang dan Ladrang Pangkur." [Skripsi]. Yogyakarta: Fakultas Seni Pertunjukan, Institut Seni Indonesia, 2011.

Sukistono, Dewanto. 1996. "Kehidupan Wayang Golek Menak di Kecamatan Sentolo Kabupaten Kulon Progo Daerah Istimewa Yogyakarta”. [Skripsi] Surakarta: Program Studi S1
Pedalangan STSI Surakarta. . 2009. "Tatahan dan Sunggingan Wayang Golek Menak Yogyakarta', dalam RESITAL.

Supanggah, Rahayu. 2009. Bothekan Karawitan II. Surakarta : ISI Press Surakarta.

Sumaryono dan Suhardjono. "Sistem Kekerabatan Seniman Dalang Pengaruhnya Pada

Kehidupan dan Perkembangan Wayang Topeng Pedalangan Yogyakarta”. [Laporan Penelitian]. Yogyakarta: Lembaga Penelitian ISI Yogyakarta.

Suparto, P. 1999. "Pertunjukan Wayang Golek Ramayana di PT. Nitour Inc. Yogyakarta." [Skripsi]. Yogyakarta: Program Studi S1 Karawitan ISI Yogyakarta.

Supriyono. 2007. "Fungsi Gending Dalam Pakeliran Jawatimuran" [makalah]. Surabaya: Taman Budaya Jl. Gentengkeli No. 85 Surabaya.

\section{b. Narasumber}

Ki Sukarno. Umur: 72 tahun. Pekerjaan: Dalang sepuh Wayang Golek Menak Yogyakarta. Alamat: Sentolo, Kulogprogo, Yogyakarta.

Ki Suparman. Umur: 62 tahun. Pekerjaan: dalang Wayang Golek Menak dan pengrajin wayang Golek Menak. Alamat: Sentolo, Kulonprogo, Yogyakarta.

Indri Kisworo. Umur: 53 tahun. Pekerjaan: Seniman karawitan. Alamat: Bantul, Yogyakarta.

Dewanto Sukistono. Umur: 43 tahun. Pekerjaan: Dalang wayang Golek Menak dan Dosen Jurusan Pedalangan Institut Seni Indonesia Yogyakarta. Alamat: Sentolo, Kulogprogo, Yogyakarta. 